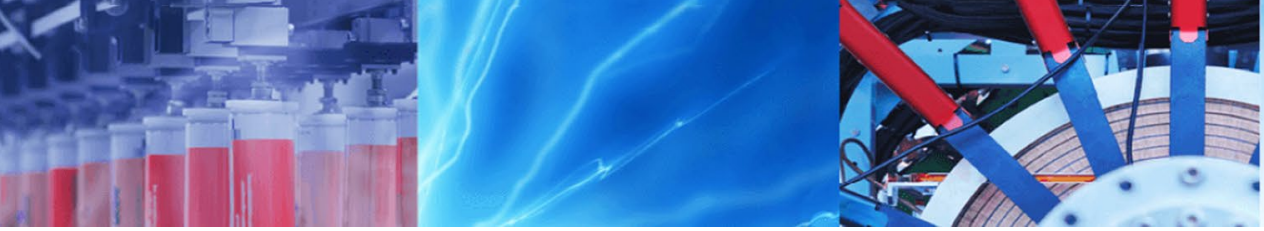

Case Study

\title{
The contribution of an urban gravity survey to the determinable perspective of Athens city (Greece) underground structure
}

\author{
Spyridon Dilalos ${ }^{1}\left[\right.$ ] John D. Alexopoulos ${ }^{1}$
}

Received: 8 June 2020 / Accepted: 28 August 2020 / Published online: 9 October 2020

(c) Springer Nature Switzerland AG 2020

\begin{abstract}
An urban gravity survey with more than 1120 measurements was carried out in order to adumbrate the deeper subsurface of Athens city basin. The aim was to gather quantitative information of the subsurface structure derived from the acquisition of gravity measurements. At first, a gravity base network has been established for the data collection. The standard data reduction has been carried out along with an additional Building Correction that has been calculated due to the urban characteristics. Subsequently, the residual anomaly was isolated with the contribution of the Fourier filters. The Euler deconvolution has been applied, with two different techniques, providing depth solutions for the residual maps. Based on these maps, we managed to retrieve quantitative information for the depths of anomalous sources, ranging between 500 and $3760 \mathrm{~m}$. Moreover, unconstrained three-dimensional density models of the area have been constructed in order to obtain a good image of the subsurface, up to depths of $4500 \mathrm{~m}$. For each three-dimensional density model, we provide a couple of images; one illustrating only the structures of lower densities and one other only with the structures of higher densities, in an effort to delineate better the tectonic structures. Finally, two geophysicalgeological profiles (2.75D) have been constructed, along which the geotectonic regime of the subsurface seems to be adumbrated in a better way. Major known tectonic structures of Athens basin have been identified beneath the surface.
\end{abstract}

Keywords 2.75D Interpretative sections · Three-dimensional density models · Euler deconvolution depths · Gravity bases - Urban gravity measurements

\section{Introduction}

The metropolis city of Greece is located in Athens basin, where 4 million people live and work. Taking into consideration the major damage caused by the devastating earthquake of 7th September $1999\left(M_{\mathrm{w}}=5.9 \mathrm{R}\right)$, the need for further and deeper investigation of the geological structure of the subsurface came up. Especially in such urban and fully residentially developed areas, the knowledge on the existence of concealed active faults is absolutely valuable. The damage distribution of an earthquake is known to depend on the tectonic pattern of the area. A small problem arises due to the fact that the artificial surfaces (buildings, roads, bridges etc.) dominate along Athens, making the geological research more difficult.

The geophysical methods can overcome this difficult situation by retrieving information for the deep subsurface. Taking into account the land cover data presented in Fig. 1, provided by CORINE 2012 project [28], the areas of artificial surfaces cover a $54.5 \%$ of our study area [21]. The land gravity survey seems the most suitable method for the deep geotectonic investigation. Gravity measurements have been applied widely the last few years contributing to the investigation of basin structure $[20,25,26,35,41$, $43,63]$.

Spyridon Dilalos, sdilalos@geol.uoa.gr; John D. Alexopoulos, jalexopoulos@geol.uoa.gr|'Division of Geophysics-Geothermic, Department of Geology and Geoenvironment, National and Kapodistrian University of Athens, Panepistiomioupoli, Zografou, Greece. 


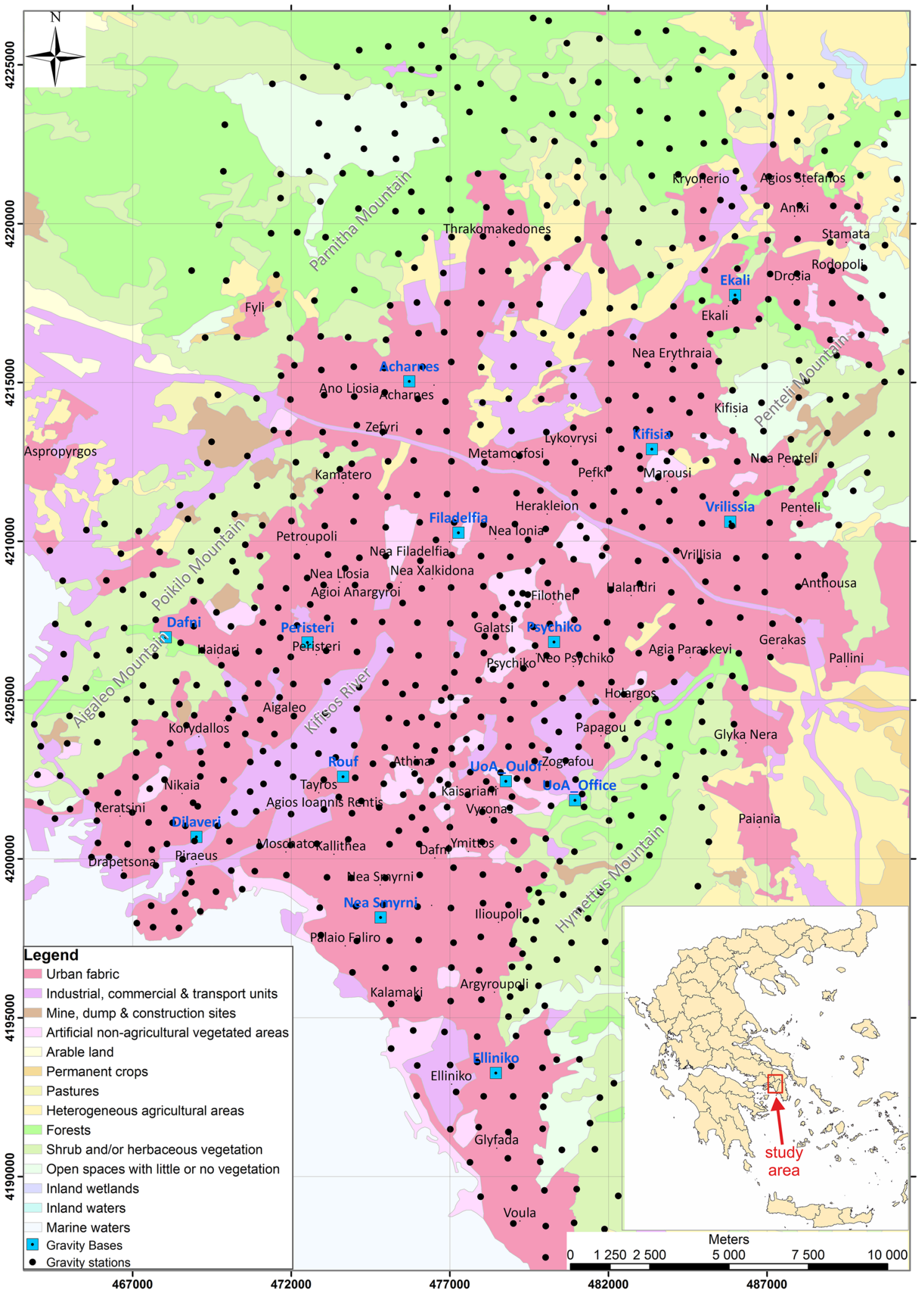

Fig. 1 Simplified land cover map of the study area, based on CORINE 2012 data. An index map is also provided 
One of the methods used in this paper is the Euler deconvolution, successfully applied in the past by other authors [18, 24, 31, 40, 59, 62, 63]. Practically, Euler methods are considered as derivatives method of first, second or even third order. The method uses three orthogonal gradients of the gravity field along with the field itself, in order to determine the location and the depth of the target. The obtained results provide us with the necessary information which will lead to the production of a set of maps, illustrating the locations and depths of the geologic sources of gravity anomalies that have been identified in grid-based gravity data. This information can help us understand better the seismotectonic structure of Athens basin.

In the context of outlining the basin subsurface structure, we will take advantage of the quantitative gravity interpretation and its three-dimensional density models that will be produced. Through their analysis, we can try to define some specific parameters, such as the location, depth, shape and density contrast of the geological bodies. Thus, gravity interpretation cannot be characterized by its uniqueness and absolute solution, due to its ambiguity problem, but any additional, data can constrain the quantification errors and limits. The real aim of the gravity inversion is to define model bodies that could realistically correspond to geological and tectonic structures.

This paper is structured in the following 4 sections. In Sect. 2 we provide detailed geological and tectonic information of the study area, which is essential for the final interpretation of the gravity results. In Sect. 3 all the steps of the gravity method are presented, beginning from the establishment of the gravity base network and the acquisition of the gravity data, then the data reduction procedures and finally the application of the Euler method, the production of the three-dimensional density models along with the $2.75 \mathrm{D}$ geological-gravity sections. In Sect. 4, a detailed presentation and discussion of the $2.75 \mathrm{D}$ geological-gravity sections is provided, in order to fully understand them. Finally, in Sect. 5 the results of the gravity survey and the geological interpretation are presented, along with the new insights for the area.

\section{Geological and tectonic setting}

The Athens basin covers an area of almost $360 \mathrm{~km}^{2}$, bounded by the mountains Hymettus (East), Parnitha (North), Penteli (Northeastern) and Aigaleo-Poikilo (West). Its geology has been studied by many authors due to its complication $[32,44,49,51,53,55-57,64,67,68,75]$.'

In Fig. 2, we provide a simplified geology regime of the area $[21,25]$ mostly based on this up-to-date geotectonic study by Papanikolaou et al. [67] but completed and combined with some of the existent studies where there was no coverage. The geological regime is quite complicated. An autochthonous metamorphic geotectonic unit covers the eastern margin (Penteli and Hymettus Mountains), while an allochthonous unit ("Ypopelagoniki") structures the western margin (Aigaleo and Poikilo mountains). Finally, there are two more local allochthonous units, "Alepovouni Unit" and "Athens Unit".

The autochthonous metamorphic unit includes dolomites but also marbles and shales, as continuous overlaying layers. The "Ypopelagoniki" unit is comprised of the Triassic-Jurassic limestones and clastic formations from Paleozoic at its base. The "Athens Unit" has practically two main parts, the upper one with limestones and the lower one (known as "Athens Schists"), which is a geological mélange including shales, sandstones, phyllites, limestones and marls. The "Alepovouni" Unit consists of limestones in its upper part, while schists and phyllites appear in the base, because of its low metamorphism. It is located tectonically between the autochthonous metamorphic unit and the "Athens" one.

The biggest part of the basin is covered by the postalpine geological formations, apart from the remaining hills in the center (Tourkovounia, Filopappou, Lycabettus, Ardittou, Acropolis, Kokkou), where the "Athens Unit" dominates. The research of Papanikolaou et al. [67] mentions more than ten different Quaternary and Neogene geological formations, which were unified in groups [21,25] for a better handling. Because of their existence, it is difficult to understand with no doubt the geotectonic regime of the basin.

The alpine tectonic regime is controlled mainly by low-angle fault zones, known as part of the West Cycladic Detachment System [15, 33, 36, 50, 76, 77]. The Alepovouni Unit is delimited by two low-angle fault zones, one with the relative autochthonous underlying Metamorphic Unit dipping to Northwest. The tectonic contact between the Alepovouni and Athens Units is considered to be a major tensile detachment zone, where metamorphic formations adjust to unmetamorphic ones, leading to the rise of the metamorphic up to the surface $[37,38,66,86]$.

\section{Gravity survey}

\subsection{Establishment of gravity bases and data acquisition}

In the past, several authors (e.g., [8, 17, 23, 45, 46, 74, 80, 83]. have discussed the establishment of absolute gravity bases networks, in several areas of the world, mostly for quite larger areas.

Taking into account the traffic jam of this over-populated metropolis and the increased time that we would 


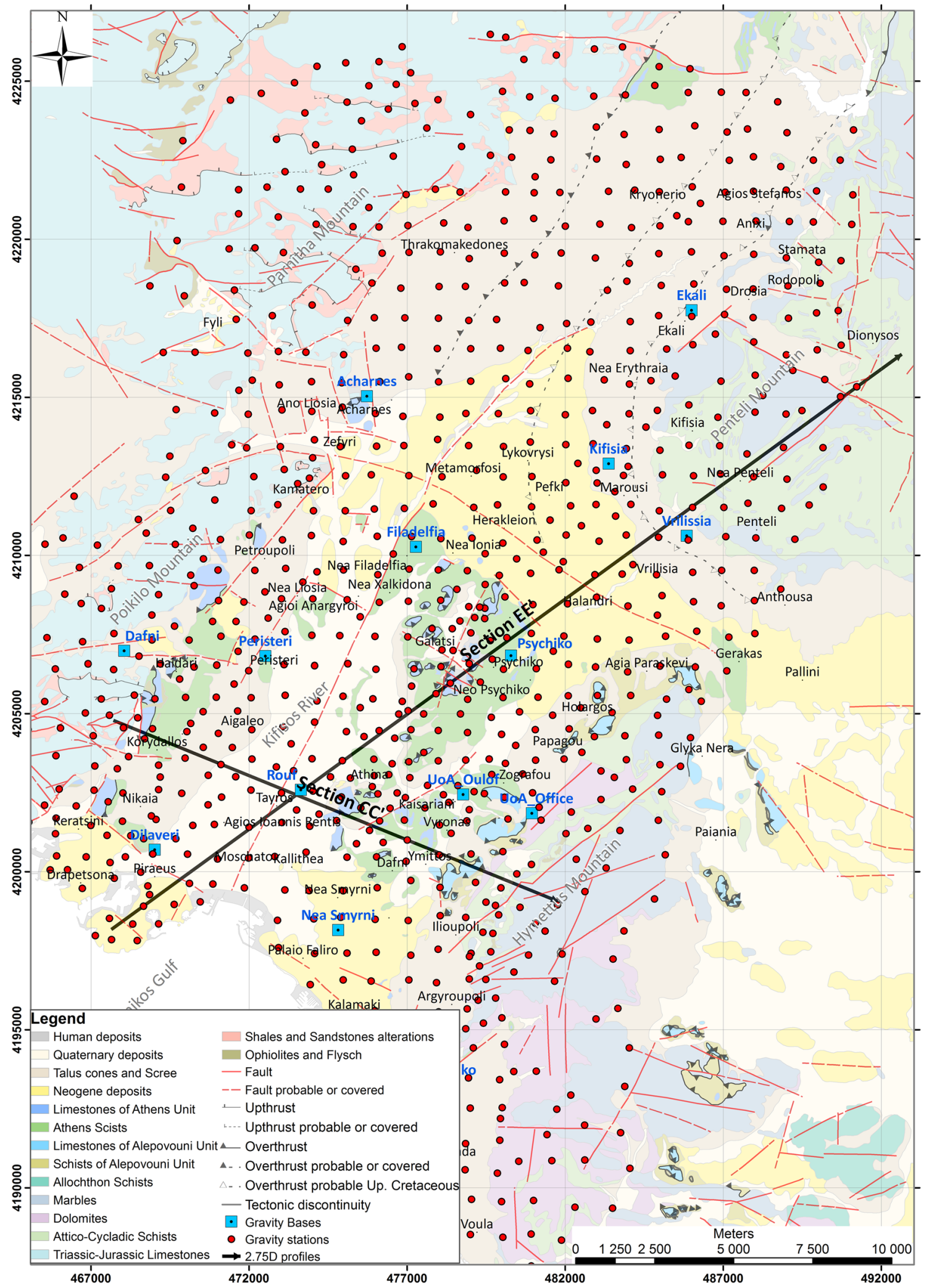

Fig. 2 Geological and tectonic map along with the locations of the gravity stations and gravity bases. The locations of the two interpretative geological-gravity profiles (sect. 3.5 ) are also illustrated 
spend moving among the stations and the base re-measurements, we planned and established very cautiously a gravity base network [23], distributing spatially fourteen (14) gravity bases (Fig. 2-blue squares) in a way that would be less time-consuming for the base loops. Each established base (Table 1) was characterized by 3 engraved permanent marks on the ground for more enduring results. In that way, the re-measurements would always be at the exact same point. Detailed sketches and photographs of each gravity base and its surrounding stable structural characteristics (columns, balusters, stairs, walls, yards etc.) were kept. The established gravity base network is referred to the IGSN'71 datum [61] as it was tied to an existing base in the University of Athens [34].

Taking into consideration the complex geology of the area and the urban characteristics, we planned the gravity survey on a grid. Because of the urban character of the study area, the gravity grid had to be organized very carefully, taking advantage of high-accuracy space images. The station grid spacing had been set primarily to $1 \mathrm{~km}$ and then some stations had been added in between the first ones, in order to clarify the status of some ambiguous areas. All the campaigns were carried out during summer (2013-2015) in order to minimize the time consumed between the stations and the bases (reduced traffic jam). The gravity meter LaCoste \& Romberg G-496 was used for the data acquisition, with an accuracy of $\pm 0.01 \mathrm{mGal}$. The gravity database is comprised of 1.122 gravity stations (Fig. 2).

In order to calculate the necessary coordinates of each gravity station and base with high precision, we used Differential Global Positioning System (dGPS), compiled by two different, dual-frequency TopCon HiperPro GPS antennas. The static technique had been chosen, because of the long distances and the blear of the buildings. In this way, the achieved accuracy of the calculated coordinates was of the centimeter scale. The coordinates were calculated in the Hellenic Geodetic Reference System (EGSA'87).

\subsection{Data processing and reduction}

The data processing and reduction of the gravity measurements have already been presented and analyzed by the authors in the past $[21,25,27]$ and for that reason we will present them briefly. The assumed constant density for the Bouguer correction was set up to $2.67 \mathrm{~g} / \mathrm{cm}^{3}$, generally used by several other researchers in the broader area $[13,54,65]$. Therefore, the Simple Bouguer Anomaly has been calculated and has been presented by [25]. In order to calculate the necessary terrain correction up to a radius distance of $21 \mathrm{~km}$, we took advantage of the Gravity and Terrain Correction extension of Oasis Montaj software. Due to the urban characteristics of the survey, we have calculated and added the Building Corrections [21, 27] caused by the gravitational attraction of the buildings and infrastructures of the city. The final construction of the Complete Bouguer Anomaly map has been presented and discussed thoroughly by [25].

Among the existing filtering processes, we chose to proceed to the regional-residual separation with the application of the Gaussian filter with a cutoff wavelength of $500 \mathrm{~m}$ that has been applied successfully in several other cases $[4,20,22,25,30]$,$) . The separation of the regional$ and residual gravity fields was based on the information provided by the corresponding Power Spectrum Analysis [25]. Based on its results, two different depths of the

Table 1 Established gravity bases in Athens (Fig. 2) along with their determined absolute values

\begin{tabular}{|c|c|c|c|c|c|}
\hline Gravity base name & $\begin{array}{l}\text { Absolute gravity } \\
\text { (mGal) }\end{array}$ & $\begin{array}{l}\text { Maximum Devia- } \\
\text { tion (mGal) }\end{array}$ & Easting (Egsa'87,m) & Northing (Egsa'87, m) & Elevation (m) \\
\hline UoA_Office & $980,010.75$ & \pm 0.00 & $480,948.310$ & $4,201,848.100$ & 252.000 \\
\hline UoA_Oulof & $980,029.86$ & \pm 0.03 & $478,772.001$ & $4,202,445.816$ & 134.792 \\
\hline Rouf & $980,049.35$ & \pm 0.04 & $473,639.680$ & $4,202,590.600$ & 20.239 \\
\hline Psychiko & $980,017.27$ & \pm 0.03 & $480,288.710$ & $4,206,831.900$ & 179.091 \\
\hline Nea Smyrni & $980,043.88$ & \pm 0.04 & $474,819.600$ & $4,198,156.400$ & 42.662 \\
\hline Peristeri & $980,044.15$ & \pm 0.07 & $472,514.450$ & $4,206,815.757$ & 51.888 \\
\hline Dilaveri & $980,052.98$ & \pm 0.08 & $469,013.766$ & $4,200,694.898$ & 7.536 \\
\hline Kifisia & $979,991.51$ & \pm 0.04 & $483,373.599$ & $4,212,901.998$ & 287.379 \\
\hline Filadelfia & $980,029.07$ & \pm 0.04 & $477,276.990$ & $4,210,270.695$ & 116.118 \\
\hline Elliniko & $980,039.12$ & \pm 0.07 & $478,453.689$ & $4,193,259.660$ & 80.884 \\
\hline Acharnes & $980,017.08$ & \pm 0.07 & $475,726.609$ & $4,215,036.626$ & 168.425 \\
\hline Ekali & $979,981.33$ & \pm 0.07 & $485,997.896$ & $4,217,756.564$ & 344.891 \\
\hline Vrilissia & $979,997.11$ & \pm 0.07 & $485,846.098$ & $4,210,619.196$ & 269.935 \\
\hline Dafni & $980,031.44$ & \pm 0.05 & $468,050.208$ & $4,206,980.671$ & 109.281 \\
\hline
\end{tabular}


anomaly sources seem to have been identified, at $2.06 \mathrm{~km}$ and $0.48 \mathrm{~km}$ depth. Subsequently, a residual map has been produced (cutoff wavelength $500 \mathrm{~m}$ ) with standard deviation of 0.25 cycles/km (Figs. 4,6 ) and a second residual map of the basement, with standard deviation of 0.02 cycles $/ \mathrm{km}$. The first one is mainly for the shallow structures, (Figs. 3, 5) while the second one ("basement residual") includes the anomaly sources and information from deeper structures of the bedrock.

\subsection{Euler deconvolution}

Although Euler deconvolution is mostly applied for the magnetics, it can sometimes be applied successfully for gravity data [39] as an approximation. The only difference is that the calculated depth solutions for the gravity method are located at a deeper level, closer to the center of the mass, in regard with the ones of magnetics.

The outcome of the Euler deconvolution here is a map, illustrating the locations and depths of the geologic sources of gravity anomalies that have been identified in grid-based gravity data, like in several other cases $[18,24$, $31,40,59,62,63]$. For the best results from Euler deconvolution, Reid et al. $[72,73]$ discuss the avoidable errors during its application to gravity data and how to determine suitably the required parameters ( $\mathrm{SI}$, window size, grid interval etc.). The grid cell of the processed data is important, since the minimum depths defined are about the same as the cell size.

One fundamental parameter for Euler deconvolution is the Structural Index (SI) value, which depends on the type of the source body, causing the gravity anomaly. In the context of this paper, we have calculated Euler depth solutions by using values equal to 0 (Figs. 3,5 ) and 1 (Figs. 4, 6), since both are considered to be close to the fault/contact type that we want to delineate. Of course, the $\mathrm{SI}=0$ is estimated to appear almost the twice the uncertainty of the one for $\mathrm{SI}=1$, which appears depth uncertainty equal to $10 \%$ and horizontal one equal to $20 \%$. Although several researchers have used non-integer values such as 0.5 for Structural Index $[78,81]$, we decided not to, based on the comments of Reid et al. [71, 73]. Additionally, Reid et al. [72, 73] propose that the SI equal to -1 is the appropriate value for finite contacts and faults in gravity surveys, but it has not been embedded as a possible value in most software and therefore we cannot test its results. The window size was set to $15 \times 15$ grid points, trying to compromise with all the conflicting requirements [72]. This means that it should be as small as possible but also greater than twice the acquired data grid spacing. Simultaneously, it should be greater than half the desired depth of investigation, which here is at least 2-3 km. Moreover, some eliminations of spurious solutions were executed, by setting some acceptable parameters, such as the maximum acceptable distance $(7500 \mathrm{~m})$, the maximum depth tolerance $(14 \%)$ and the maximum horizontal tolerance (35\%).

The Euler deconvolution has been carried out with the Euler3D extension of Oasis Montaj software and more specifically with two different methods, the Standard Euler (Figs. 3, 4) and the Located one (Figs. 5, 6). The second one produces far fewer spurious solutions (Figs. 5,6 ) since it is based only at the areas with existing anomalies (picks) in the analytic signal. The input grid data were the residual and the basement residual ones. The generated Euler depth solutions from both input data were merged and presented together in order to have a common image that would lead to an easier evaluation.

The produced solutions for the Structural Index zero (0) are located mainly around the main low-gravity spherical area (Thrakomakedones, Kryoneri, Ekali, Nea Erythraia, Lykovrysi, Acharnes) observed in the basement residual map, with depths mostly between 500 and $1500 \mathrm{~m}$ and some deeper (1500-2300 m) at the southwest corner. Moreover, we observe solutions of depths ranging from 500 to $1000 \mathrm{~m}$ along two linear areas. The first area is located at the western foothills of Hymettus Mountain, from Anthousa to Kaisariani and the second one is at the southern foothills of Parnitha Mountain, along Agios Stefanos and Drosopigi. Additionally, solutions for depths from 500 up to $1500 \mathrm{~m}$ are observed at the southern suburbs of Athens basin, along smaller areas, such as Agios loannis Rentis-MoschatoKallithea, Nea Smyrni-Agios Dimitrios, Kalamaki-Elliniko and Elliniko-Glyfada. The solutions clusters are more extended and systematic in the Standard Euler technique, while the solutions in the Located Euler are constrained a lot. On the other hand, there are not large differentiates of depths and locations between the two methods.

For Structural Index equal to one (1), the number of the produced Euler solutions is quite higher (Figs. 4, 6), especially for the ones produced through the Standard Euler procedure. It seems that we have enough correlations between the locations of the solutions and possible or existing fault zones. For $\mathrm{SI}=1$, we can also observe great clusters of solutions around the margins of the main low-gravity area, similar to the $\mathrm{SI}=0$ ones. The calculated depths are bigger, reaching up the $3760 \mathrm{~m}$, when the $\mathrm{SI}=0$ gave maximum depths up to $2300 \mathrm{~m}$ and quite restricted in swarm. Furthermore, the two linear areas of solutions, presented for $\mathrm{SI}=0$ (Figs. 3, 5), along the foothills of Parnitha and Hymettus Mountains, also appear with greater calculated depths (up to $3760 \mathrm{~m}$ for Parnitha Mt and up to $2000 \mathrm{~m}$ at Hymettus Mt.) and expanded in length. This means that the one is running along Anthousa-Agia Paraskevi-Holargos-Kaisariani-Argyroupoli-Kalamaki and the other along Agios Stefanos-Drosopigi. For the linear areas 


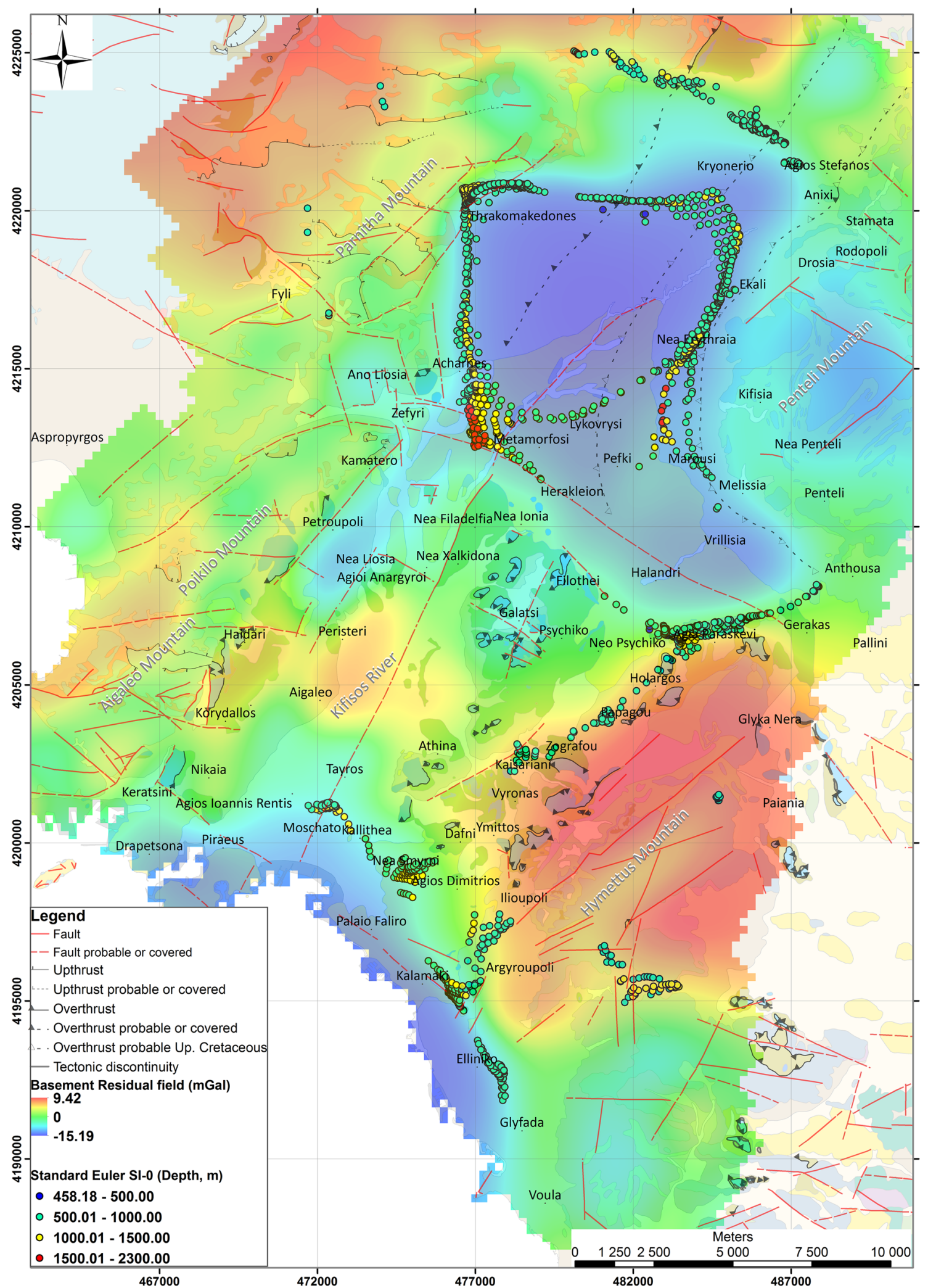

Fig. 3 Standard Euler solutions (graduated symbols with depth) for $\mathrm{SI}=0$ along with the Residual Map of Athens basin, illustrating the deeper bedrock anomaly sources 


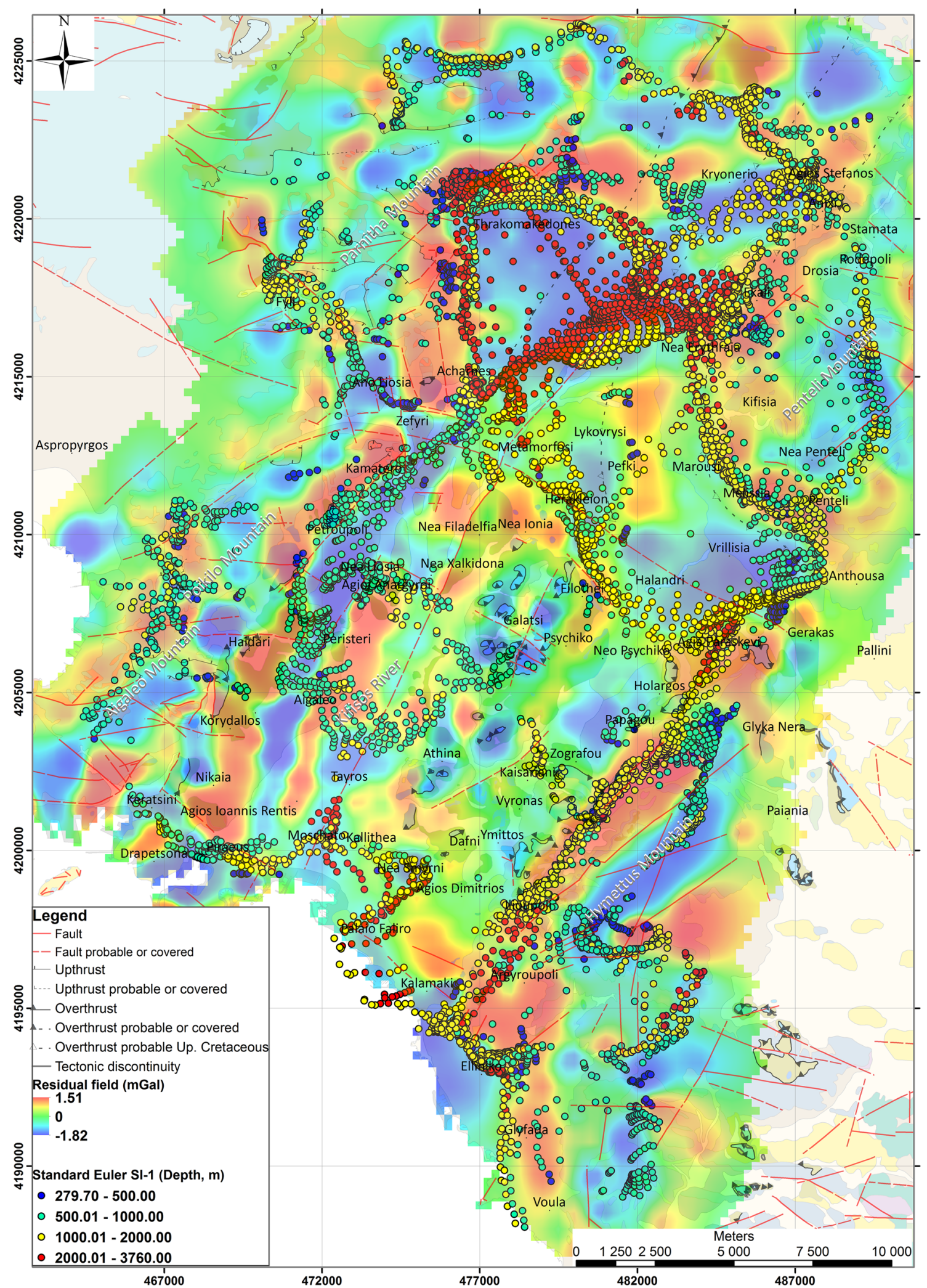

Fig. 4 Standard Euler solutions (graduated symbols with depth) for $\mathrm{SI}=1$ along with the Residual Map of basement, illustrating the shallow anomaly sources 




Fig. 5 Located Euler solutions (graduated symbols with depth) for $\mathrm{SI}=0$ along with the Residual Map of Athens basin, illustrating the deeper bedrock anomaly sources 


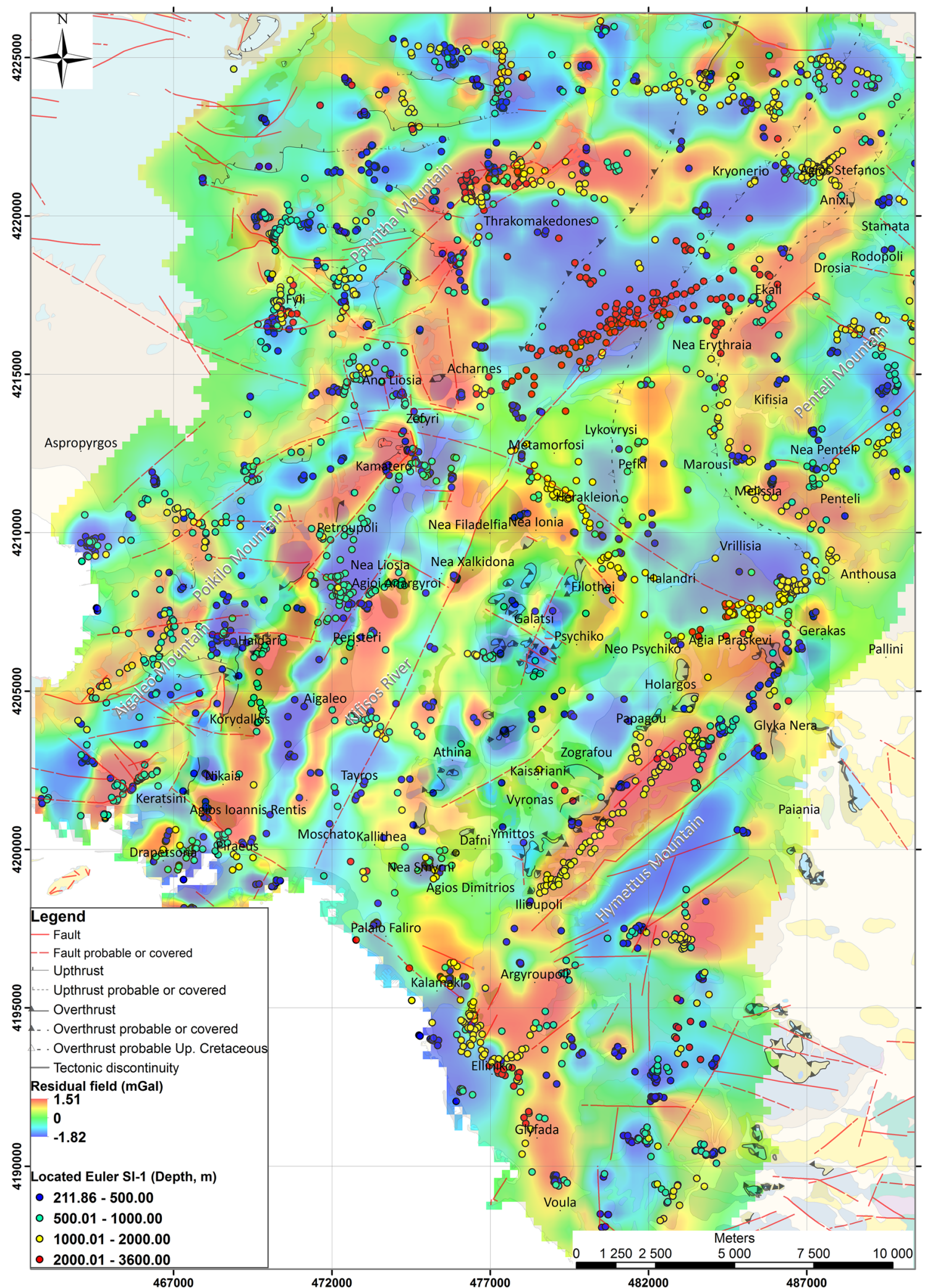

Fig. 6 Located Euler solutions (graduated symbols with depth) for $\mathrm{SI}=1$ along with the Residual Map of basement, illustrating the shallow anomaly sources 
located in the southern suburbs, we can also observe larger depths.

Beyond the clusters of solutions detected for both Structural Indexes 0 and 1 , by setting $\mathrm{SI}=1$ we observe new clusters of solutions, in other areas, located in the central and western part of the basin. More specifically, clusters of solutions for depths $500-1,000 \mathrm{~m}$ are spotted along the zone Zefyri-Kamatero-Petroupoli-Haidari, Keratsini-Drapetsona-Piraeus, Agioi Anargyroi-Peristeri, AigaleoVotanikos-Downtown-Psychiko, Penteli and Hymettus Mt. For bigger depths $(1,000-2,000 \mathrm{~m})$ along Nea PenteliMelissia-Marousi-Nea Erythraia, Agia Paraskevi-HalandriHerakleion-Metamorfosi-Acharnes, Kryoneri-Agios Stefanos and Piraeus-Faliro-Moschato. At the areas of Fyli and Poikilo-Aigaleo mountains, the depths of solutions range from 500 to $2,000 \mathrm{~m}$.

\subsection{Three-dimensional density models}

The three-dimensional gravity modelling has been evolved rapidly during the last years $[7,9,12,14,16,19,29$, $58,70,82,84]$. Three-dimensional modelling of the gravity data provides us with information concerning the volume and geometry of the anomalous sources that cause gravity anomalies and can be a powerful tool for geological interpretation. The density model is constructed based on a mesh of blocks/cells of equal dimensions, specified from the beginning, each one characterized by a certain value of density or density contrast.
All the density inversions within the context of this paper have been carried out using the "VOXI" Earth modelling module $[7,29,59,85]$ of Oasis Montaj by Geosoft. They have been integrated with the defined densities of the geological formations, derived from the application of three different methods [21,25]. Therefore, we managed to determine the density of all the formations, even of the ones compiled of different lithologies, such as the Neogene formations and the Athens Schists.

We applied the unconstrained three-dimensional gravity modelling on both Complete Bouguer Anomaly data and the Residual anomaly data in order to compare the results, based on the fact that for the Complete Bouguer Anomaly, a trend removal procedure has to be first applied. Insignificant differences derived, proving that the trend removal procedure is reliable. The inversion results were almost identical with those of the Residual data, where the regional field has already been removed with the FFT. The desired absolute error was $5 \%$.

We discretized the subsurface in a three-dimensional block mesh, with blocks that have a cell size equal to $1000 \mathrm{~m}$ for $\mathrm{X}-\mathrm{Y}$ and $500 \mathrm{~m}$ for $\mathrm{Z}$ direction (Fig. 7). Therefore, the subsurface area was divided in a total of 12,760 blocks of individual density contrast. The density contrast ranges from $-0.32 \mathrm{~g} / \mathrm{cm}^{3}$ (bluish colors) to 0.669 $\mathrm{g} / \mathrm{cm}^{3}$ (reddish colors) for depths up to $6800 \mathrm{~m}$ (or else absolute elevation - $5300 \mathrm{~m}$ ). In Fig. 8, we provide an alternative pseudo-three-dimensional view based on the
Fig. 7. Three-dimensional gravity inversion of Athens basin, with cell size of $1000 \mathrm{~m}$ (mesh $40 \times 29 \times 11$ blocks). The area's DEM is presented as the upper plane and is the Residual Anomaly ( 0.02 cycles/ $\mathrm{km}$ ) as the lower one

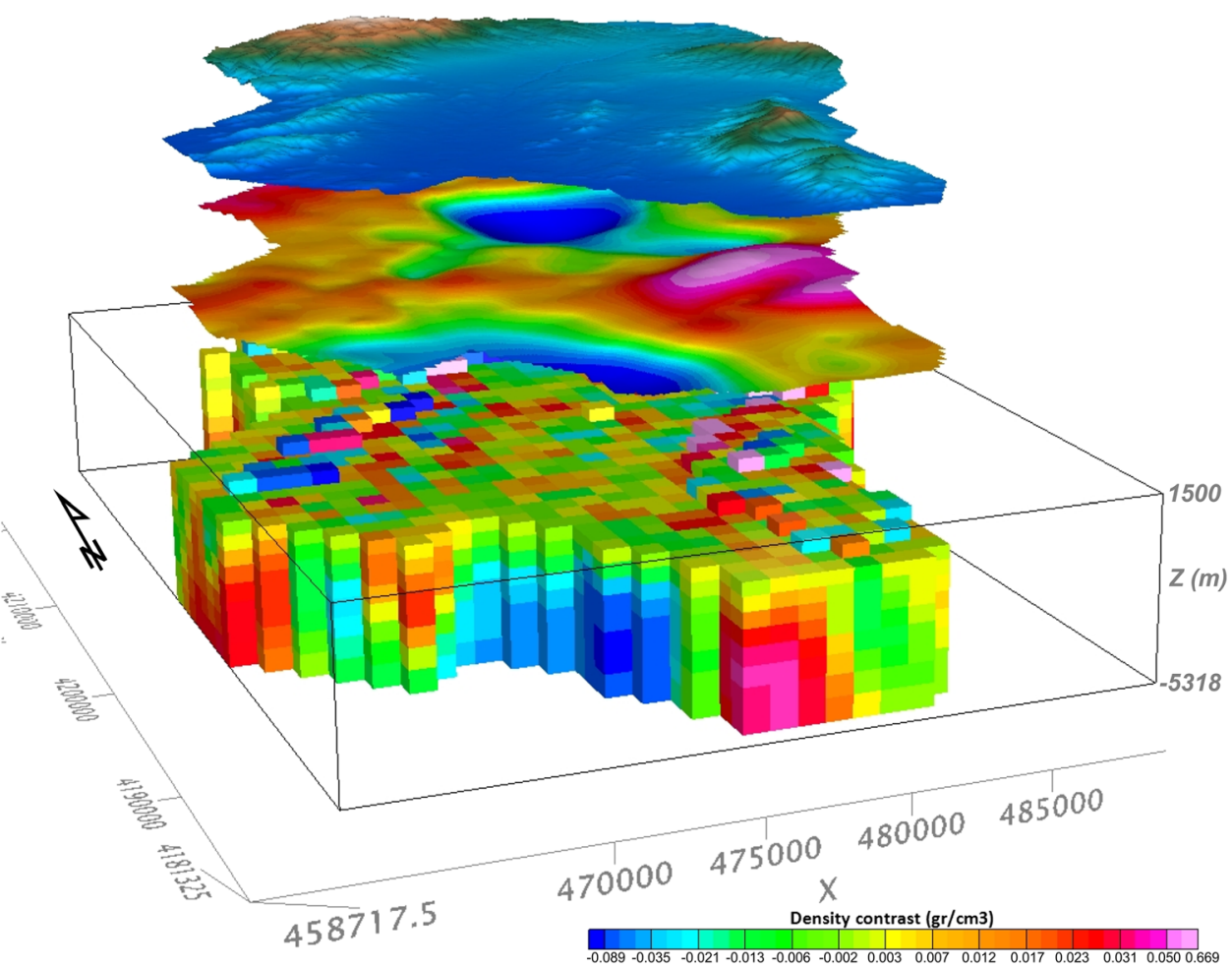

SN Applied Sciences A SPRINGER NATURE journal 


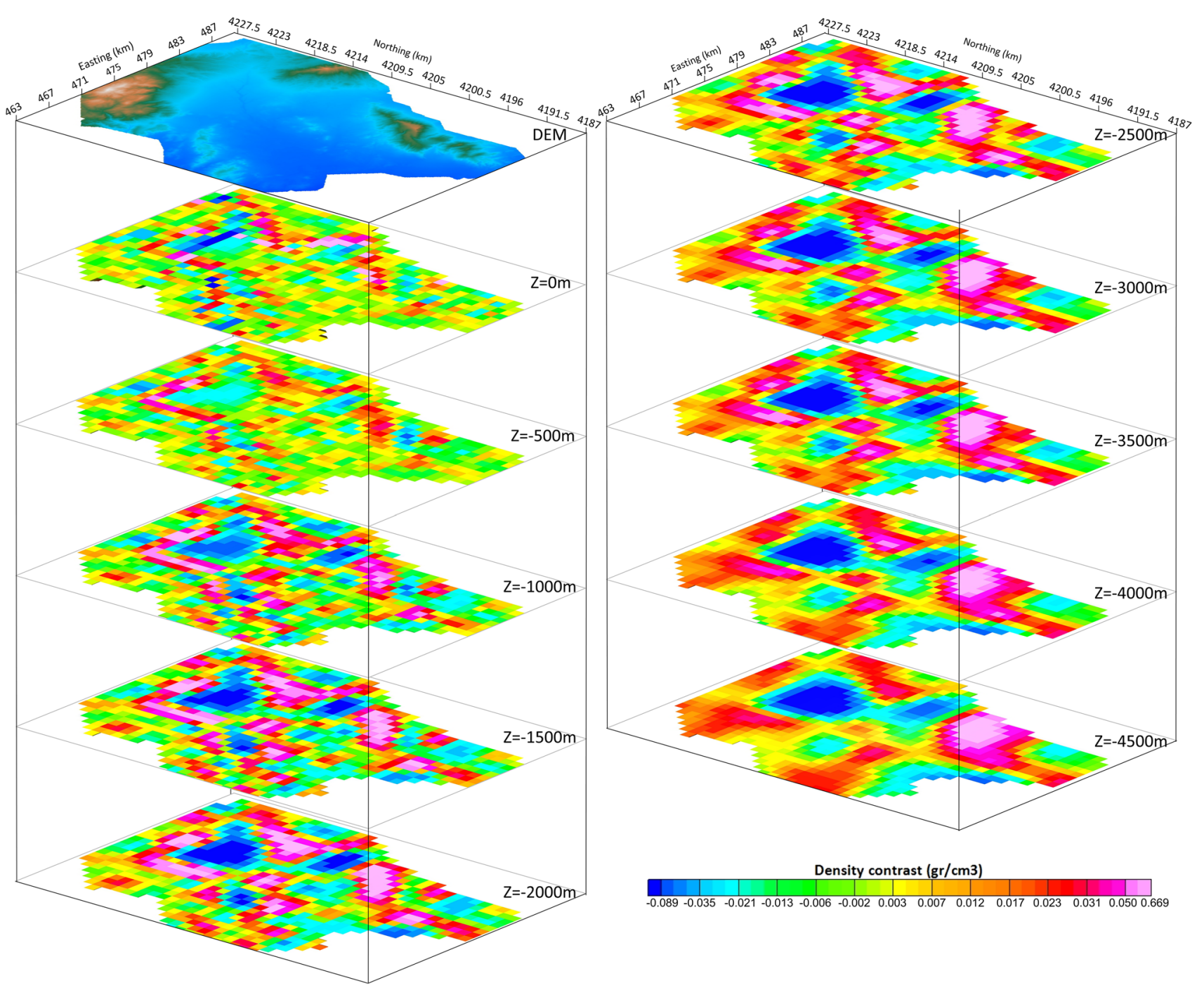

Fig. 8 Depth slices of the three-dimensional gravity inversion model of Athens basin. The upper left plane illustrates the DEM of the area

depth slices $[2,3,9,60,82]$ of the inversion model we have calculated for a better understanding of the subsurface density structure.

In Fig. 9, we have isolated the bodies with negative density contrast (ranging from -0.32 to $-0.02 \mathrm{~g} / \mathrm{cm}^{3}$ ) at the areas of Thrakomakedones, Kryoneri, Drosia, Kifisia, Melissia, Vrilissia, Halandri, Herakleion, Metamorfosi, Acharnes, Petroupoli, Agioi Anargyroi, Piraeus, Palaio Faliro and Kalamaki producing the low gravity anomalies in the Residual maps (Figs. 3, 4, 5, 6). In Fig. 10, below the areas of Mountains Hymettus, Aigaleo-Poikilo, Parnitha and the downtown of Athens city, the bodies with positive density contrast $\left(0.02-0.67 \mathrm{~g} / \mathrm{cm}^{3}\right)$, producing the high gravity anomalies have been adumbrated. These bodies define the geometric boundaries of the anomalies, producing both low and high gravity values respectively. The DEM and the Residual maps have been positioned above the three-dimensional model of the area for a better understanding and evaluation of the results.

Taking into consideration the anomalies already observed in the general model (Figs. 9, 10), additional inversions were carried out for smaller areas, in order to reduce the cell size down to $500 \mathrm{~m}$ (Figs. 11, 12, 13, 14) or even $250 \mathrm{~m}$ for the horizontal directions. This would provide greater detail of the final three-dimensional density model and consequently better adumbration of the geometry of the source bodies.

The results of the three-dimensional models (Figs. 7, $8,9,10,11,12,13,14)$ are quite impressive and revealed important subsurface structures that might play important role for the seismotectonic structure of Athens basin. Several fault zones already mapped are verified by these models and more information about their characteristics might be gained (e.g., throw, depth and 
Fig. 9. Three-dimensional gravity inversion results (cell size $1000 \mathrm{~m}$ ), illustrating the structures of low densities (density contrast from -0.32 to $-0.02 \mathrm{~g} / \mathrm{cm}^{3}$ )
Fig. 10. Three-dimensional gravity inversion results (cell size $1000 \mathrm{~m}$ ), illustrating the structures of high densities (density contrasts from 0.02 to $0.67 \mathrm{~g} / \mathrm{cm}^{3}$ )
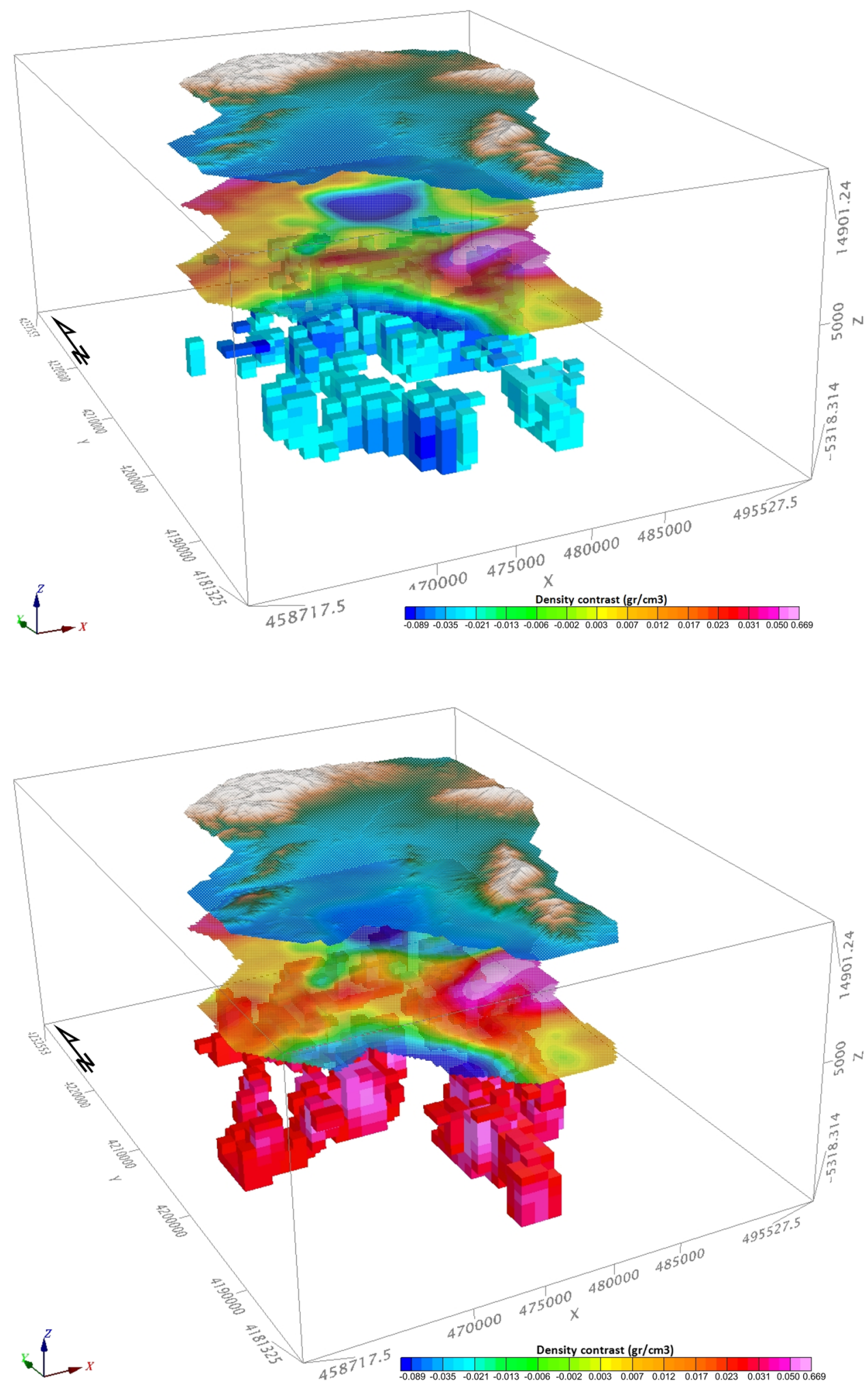

dip). But the most significant contribution of the threedimensional density models is that they also validate the existence of several fault zones mapped as possible (blind faults), based on other criteria.

\subsection{75D geological-gravity modelling}

Interpretative geological-gravity profiles have been constructed, with the contribution of GM-SYS $[1,6,10$, 
Fig. 11. Three-dimensional gravity model (cell size $500 \mathrm{~m}$, mesh $42 \times 45 \times 17$ blocks), showing structures of low densities (density contrast from -0.24 to $-0.02 \mathrm{~g} / \mathrm{cm}^{3}$ ) in the area of Thrakomakedones, Acharnes, Metamorfosi, Acharnes and Petroupoli
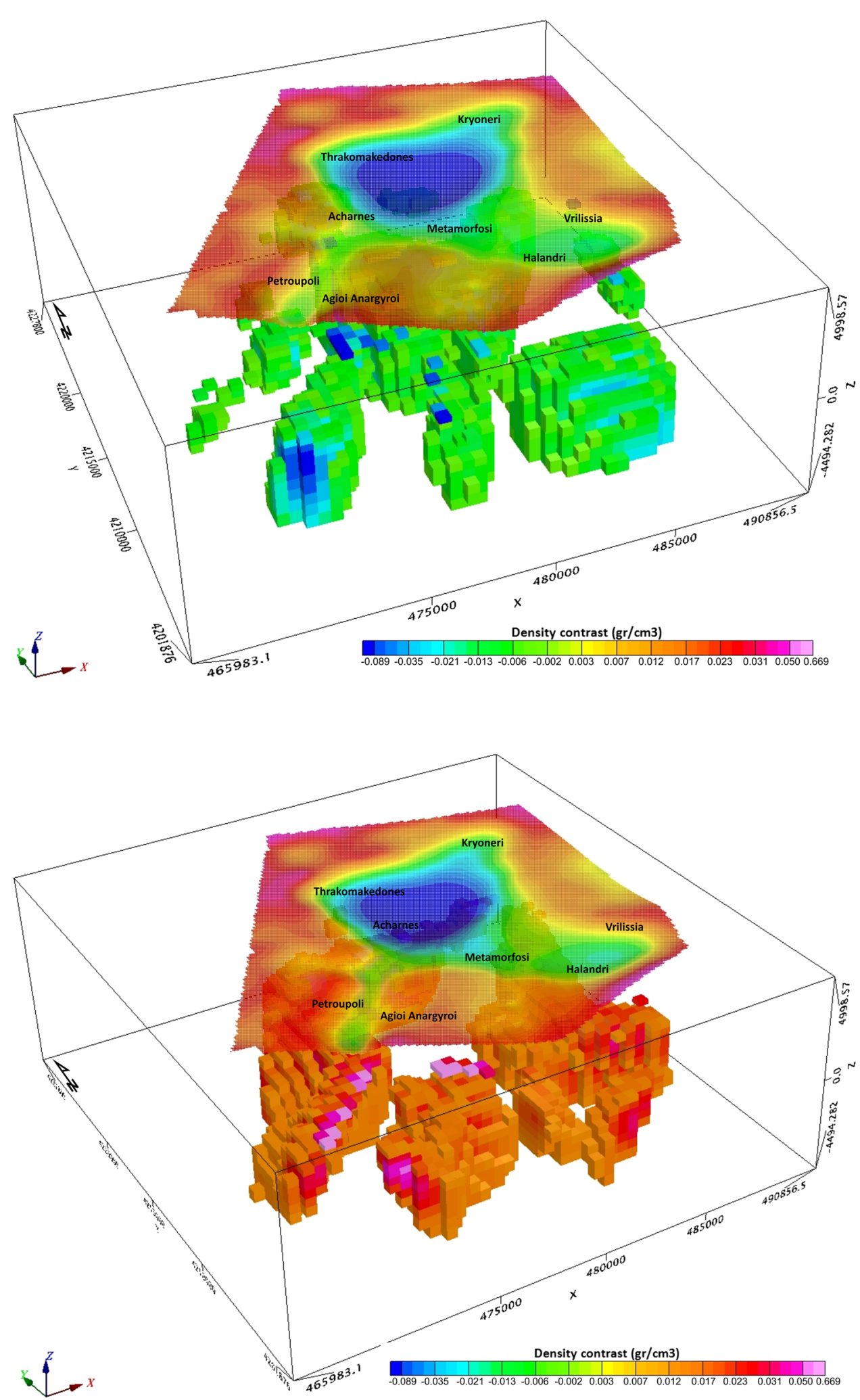

Fig. 12. Three-dimensional gravity model (cell size $500 \mathrm{~m}$, mesh $42 \times 45 \times 17$ blocks), showing structures of high densities (density contrast from 0.02 to $0.41 \mathrm{~g} / \mathrm{cm}^{3}$ ) in the area of Thrakomakedones, Acharnes, Metamorfosi, Acharnes and Petroupoli
$11,25,26,42,48,69,79,85]$. It is a program by Geosoft for calculating the gravity response from a geological cross-section, compared to the observed field anomaly response. The models in GM-SYS are built with polygons that represent different geological formations and a density value is assigned at each one. The $2.75 \mathrm{D}$ models can have two-dimensional prisms asymmetrically positioned

\section{SN Applied Sciences}


Fig. 13. Three-dimensional mesh $44 \times 46 \times 13$ blocks), showing structures of low densities (density contrast from -0.26 to $-0.02 \mathrm{~g} / \mathrm{cm}^{3}$ ) in the area of Haidari, Peristeri, Athens and Hymettus Mt gravity model (cell size $500 \mathrm{~m}$,

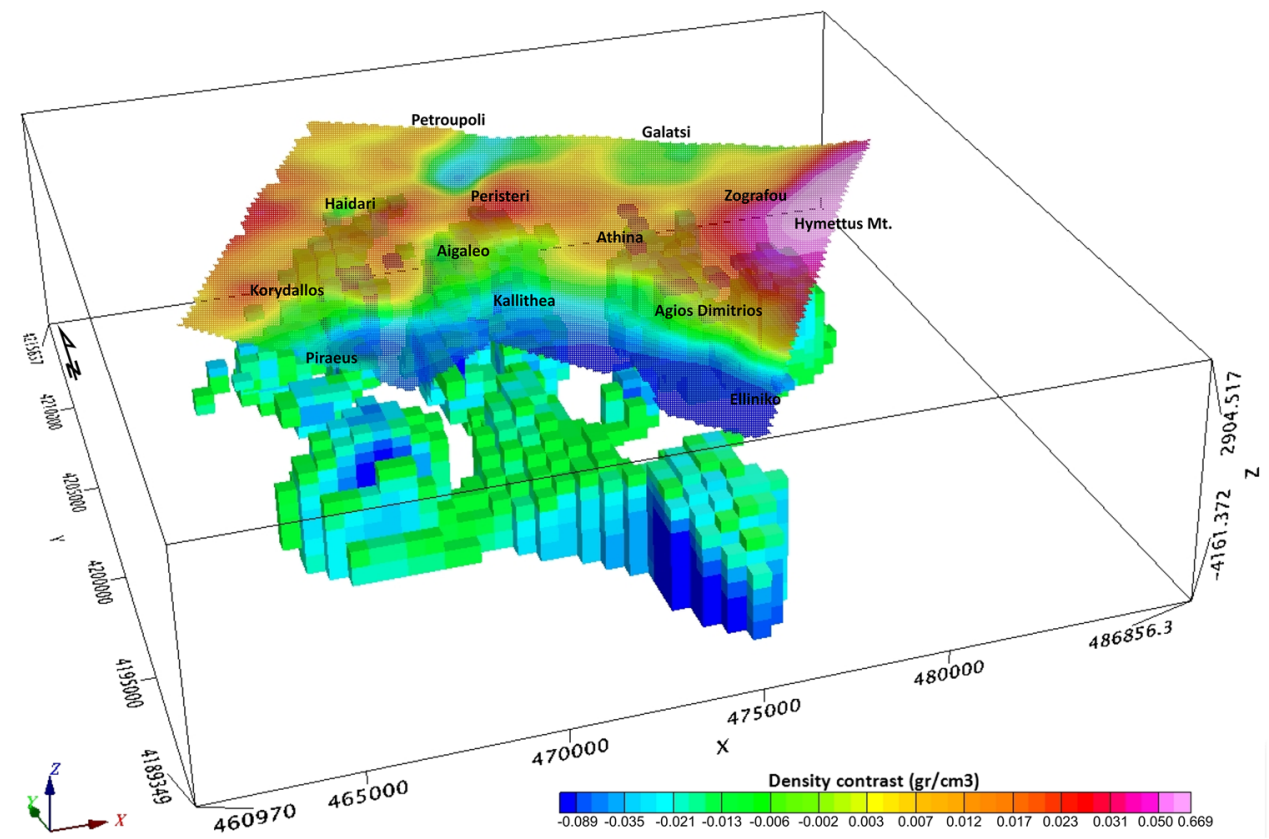

Fig. 14. Three-dimensional gravity model (cell size $500 \mathrm{~m}$, mesh $44 \times 46 \times 13$ blocks), showing structures of high densities (density contrast from 0.02 to $0.49 \mathrm{~g} / \mathrm{cm}^{3}$ ) in the area of Haidari, Peristeri, Athens and Hymettus Mt

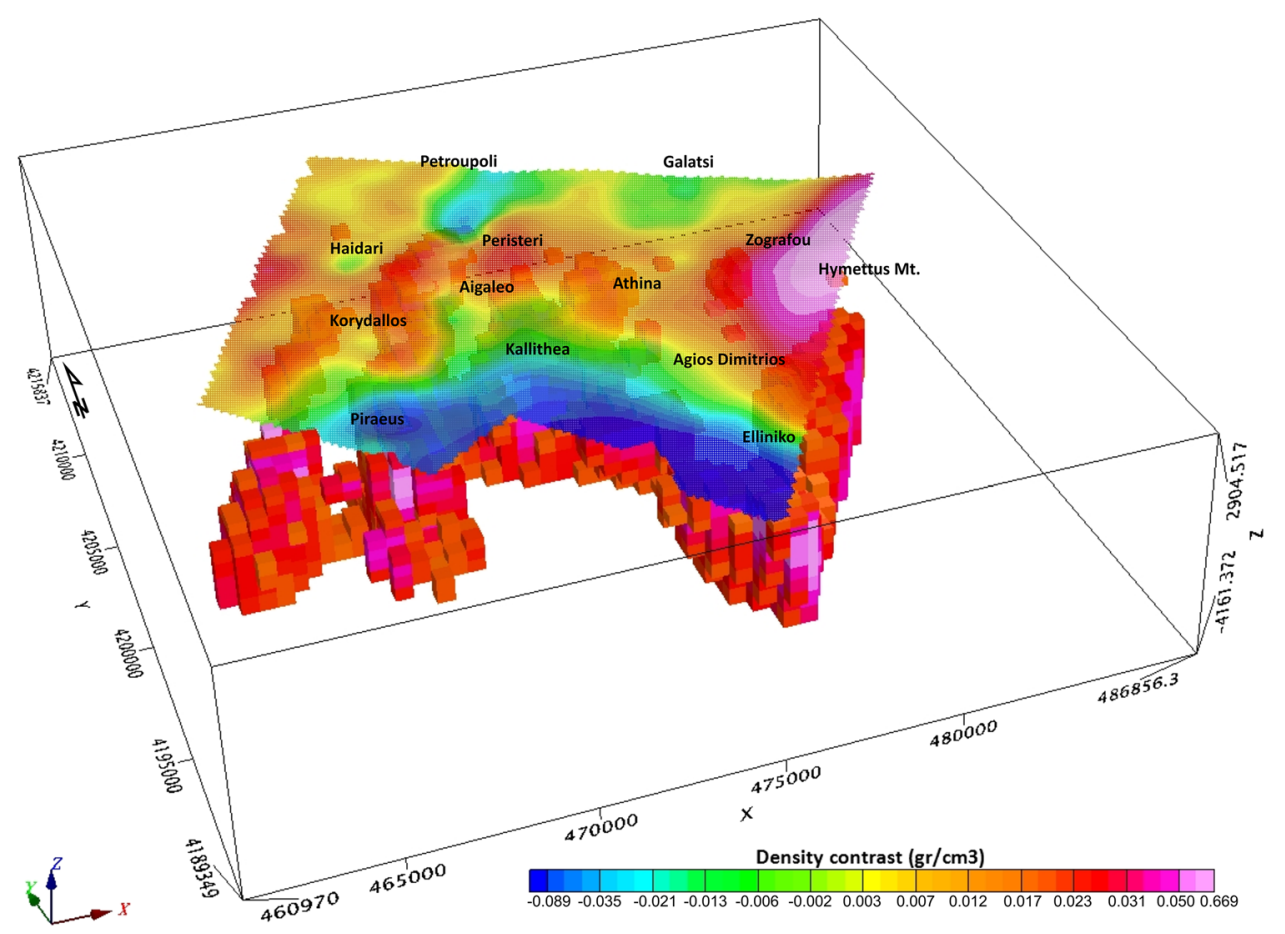

and extended at some distance from the line of the profile, in the strike direction.

In Fig. 2, the location of the profiles along the Athens basin, selected to create the interpretative geologicaldensity 2.75-D models, is presented. Two (2) sections have been constructed (Fig. 15) in order to contribute to the adumbration of the tectonic framework of the Athens basin subsurface. The density values assigned to each block/prism are based on the values proposed by Dilalos
[21] and Dilalos et al. [25]. In each of these figures, the upper part illustrates the observed residual gravity data (squares) along with the calculated one (line) based on the geological model, which is illustrated on the lower part of the figures. Each block colored differently, simulates a geological body, with a certain density quoted in the brackets. The sections are presented with a scale 1:2, therefore, there is a vertical exaggeration for better presentation and understanding. 

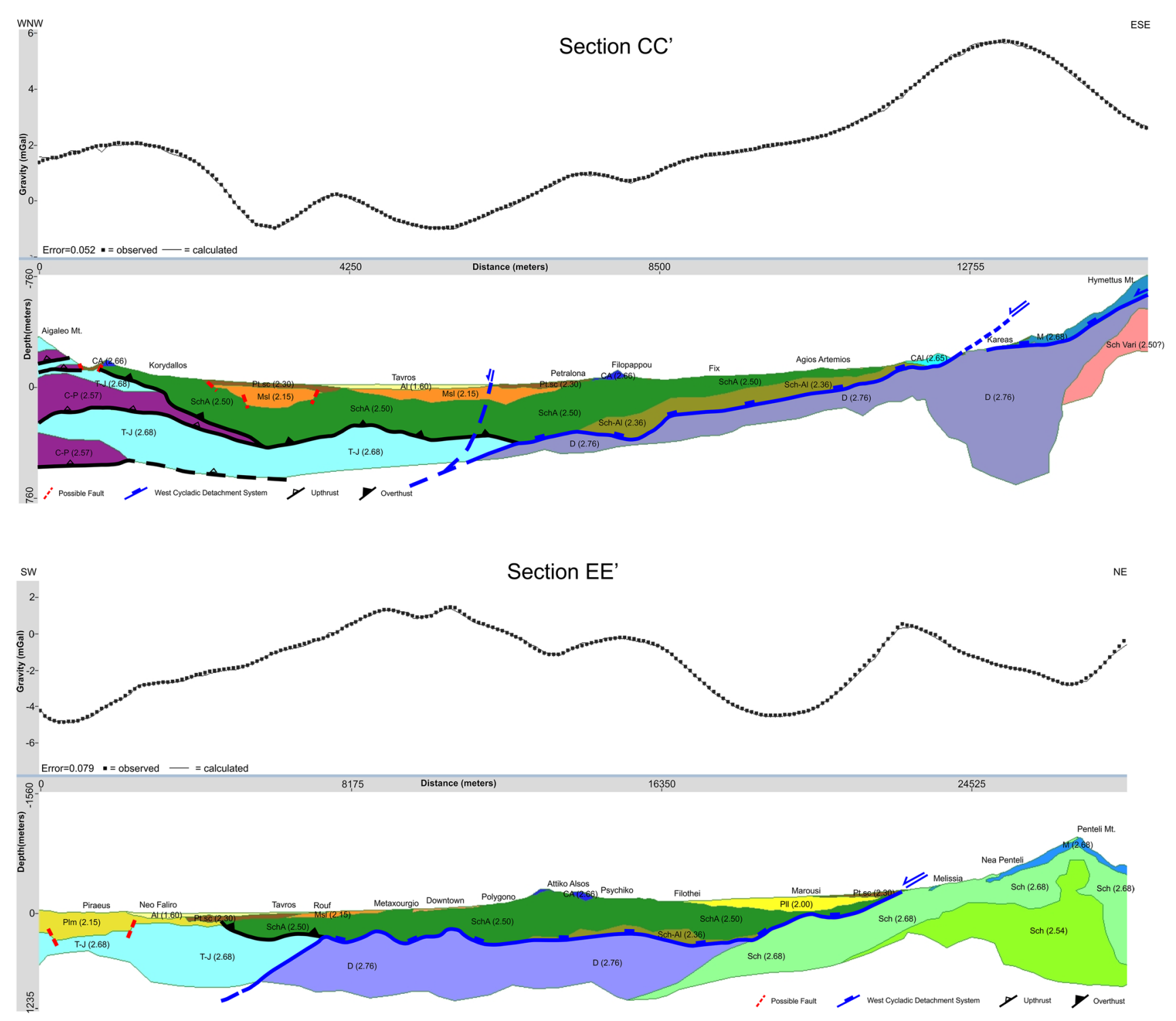

Fig. 15 Interpretative geological 2.75-D profiles (scale 1:2). The observed (squares) and calculated (line) residual anomaly are illustrated. The geological formations are: T-J: Triassic-Jurassic Limestones (Ypopelagoniki Unit), C-P: Shales and Sandstones alterations (Ypopelagoniki Unit), M: Marbles (Metamorphic Unit), Sch: Schists (Metamorphic Unit), D: Dolomites (Metamorphic Unit), Sch-Vari: Varis

\section{Discussion}

In Section CC' (Fig. 15), the Neogene deposits (Msl) are observed with thickness, up to $150 \mathrm{~m}$ and lateral coverage below the areas of Agios loannis Rentis and Tavros, producing the low residual values (down to $-1 \mathrm{mGal}$ ). There is also a layer of $40-50 \mathrm{~m}$ of Alluvium deposits $(A /)$ and Pleistocene Talus and Screes (Pt.sc), overlying. Between the areas of Korydallos and Tavros, a few neotectonic fault zones have been discovered beneath the Neogene deposits and their underlying formation of Athens Schists.
Schists (Metamorphic Unit), SchA: Athens Schists (Athens Unit); CA: Limestones (Athens Unit), Sch-Al: Schists (Alepovouni Unit), CAl: Limestones (Alepovouni Unit), Msl: Upper Miocene Terrestrial and Lacustrine deposits (Neogene Formations), Pt.sc: Pleistocene Talus and Screes, Al: Alluvium deposits (Loose Quaternary deposits)

A great part of the subsurface, beneath the Neogene deposits, is covered by the Athens Schists $(S c h A)$ and the Schists of Alepovouni Unit (Sch-Al), with a maximum thickness of 300 and $155 \mathrm{~m}$ correspondingly. Furthermore, the Dolomites $(D)$ of the Metamorphic Unit seem to dominate at the lower area below the basin (from depths of $350 \mathrm{~m}$ ) and the Hymettus Mountain, with thickness that reaches $950 \mathrm{~m}$. The Marbles $(M)$ are also detected below Hymettus Mountain, while the Schists ( $S C h$ ) have been restrained to a thin layer of a few meters. A structure similar to the one of extension-parallel folds $[5,47,52]$ seems to appear 
among the formation of the Metamorphic Unit. The formation of Varis Schists (Sch Vari) is also illustrated underlying the Dolomites $(D)$ at the end of the section.

In Section EE' (Fig. 15), the Neogene deposits are observed below the areas of Piraeus (PIm) and Marousi (PII), with thickness, up to 250 and $200 \mathrm{~m}$ correspondingly, producing the low values in the residual gravity field (down to $-4.8 \mathrm{mGal}$ ). At the area of Piraeus and Neo Faliro a couple of neotectonic fault zones have been revealed at the basement of the post-alpine deposits. There is also a layer of $40-50 \mathrm{~m}$ of Alluvium deposits (Al) partially overlying the PIm sediments at Piraeus area. The first part of the section is dominated by the existence of the Triassic-Jurassic Limestones $(T-J)$. The Athens Schists $(S c h A)$, with great surface exposure (outcrops), also cover a great part of the subsurface, with maximum thickness up to $600 \mathrm{~m}$, mostly below the central area of the basin. The Schists of Alepovouni Unit (Sch-Al) have been determined with a thin layer of maximum thickness of $200 \mathrm{~m}$, below the Athens Schists. At the central area of the profile (from depths of $300 \mathrm{~m}$ ) and below the Penteli Mountain, the Dolomites $(D)$ of the Metamorphic Unit seem to dominate, with thickness that reaches $750 \mathrm{~m}$. The Schists (Sch) seem to dominate against the Marbles $(M)$ below Penteli Mountain, since they appear with thicknesses up to 1,750 and $100 \mathrm{~m}$ correspondingly.

There are some common major fault zones that have been delineated along both sections. The West Cycladic Detachment System $[15,33,36,50,76,77]$ seems to have been identified, along which the underlying metamorphosed Metamorphic Unit is moving upward relatively to the overlying tectonic units of Ypopelagoniki, Athens and Alepovouni. The schists of Alepovouni Unit (Sch-Al) or the Athens Schists (SchA) are mostly located overlying. The dolomites $(D)$, schists $(S c h)$ or even the marbles $(M)$ of the Metamorphic Unit are located underlying. Furthermore, three to four upthrusts between the Triassic-Jurassic limestones $(T-J)$ and the Shales and Sandstones alterations $(C-P)$ seem to have been recognized. Beyond that, a thrust fault with the Athens Schists ( $S c h A$ ) of the Athens Unit overlaying tectonically on the Ypopelagoniki Unit can also be observed along both sections.

\section{Conclusions}

In this paper, the quantitative results of an urban gravity survey of Athens city basin have been presented. More specifically, a total of 1120 gravity measurements were acquired, based on a grid plan and supported by a newly established gravity base network. Due to the difficulties raised from the urban characteristics of the area, the acquisition planning was organized very carefully. Beyond that, during the standard reduction processing, an additional Building Correction has been added in order to remove the gravitational effect of the buildings on the measurements.

The next step involves the application of the Euler deconvolution in order to calculate depth solutions for the residual maps of the area. Two different techniques have been applied, the Standard Euler and the Located one but also two different Structural Indexes (0 and 1). At first, it seems that the Standard Euler method (Figs. 3,4 ) provides better results and far more solutions than the Located one (Figs. 5, 6). One the other hand, the Structural Index 0 (Figs. 3,5 ) produces less solutions than the Structural Index 1 (Figs. 4, 6). Additionally, the Euler deconvolution depth solutions (Figs. 3, 4, 5, 6), for both selected Structural Indexes ( 0 and 1$)$ and for both applied Euler deconvolution methods (Standard and Located), seem to have great similarities to the structural maps presented by Dilalos [21] and Dilalos et al. [25]. The calculated depths are ranging close to the source depths that have been estimated by the Energy Spectrum Analysis, except for some solutions of $\mathrm{SI}=1$ that reach greater depths. Based on these maps, we managed to retrieve quantitative information for the depths of anomalous sources, ranging between 500 and $3760 \mathrm{~m}$.

Furthermore, the unconstrained three-dimensional density model of the area has been constructed (Figs. 7, 8) in order to obtain a good image of the density distribution of the subsurface. The model information reaches the depth of $4500 \mathrm{~m}$, which is considered quite important for the area. For a better understanding of the three-dimensional density distribution and in an effort to delineate better the tectonic structures, we selected to present it in two separate images; one illustrating only the structures of lower densities and one other only with the structures of higher densities (Figs. 9, 10, 11, 12, 13, 14). Figures 9, 10 present the whole study area, while Figs. 11, 12, 13, 14 present two focused areas in detail.

Finally, two geophysical-geological profiles (Fig. 15) have been constructed and presented. Practically, along with these two sections we present the geological interpretation of the gravity survey, providing valuable new information for the geotectonic regime of the subsurface. Along with these sections several geotectonic structures have been adumbrated, such as neotectonics fault zones, upthrusts, thrust fault, extension-parallel folds and a structure evaluated as the West Cycladic Detachment System. Beyond these, the thickness of several geological formations has also been estimated. For example, the Neogene deposits appear with $250 \mathrm{~m}$ maximum thickness, the Athens Schists ( $S c h A)$ with $600 \mathrm{~m}$ and the schists of Alepovouni Unit (Sch-Al) with $200 \mathrm{~m}$. Additionally, the Dolomites (D) and the Schists (SCh) appear with thickness 950 and $1750 \mathrm{~m}$ correspondingly. 
The 2.75D interpretative profiles and the three-dimensional density models revealed important subsurface structures for the geotectonic structure of Athens basin subsurface, for depths up to $2500 \mathrm{~m}$. Several fault zones already mapped are verified by these models $[21,25]$ and more information about their characteristics might be gained (e.g., throw, depth and dip). But the most significant contribution is that, along with the Euler deconvolution depths, they also validate the existence of several fault zones mapped as possible (blind faults), based on other criteria. The three-dimensional density models (Figs. 7, 8, $9,10,11,12,13,14)$ define in a good way the geometry of the identified anomaly bodies and therefore the geometry of the subsurface geology.

Acknowledgements We would like to thank Dr. Stylianos Lozios for his geological advice and important guidance during the interpretation of the data. Additionally, we would like to thank Mr. Stylianos Chailas for the provision of the data for the existing gravity base in the University of Athens. The authors would also like to thank Ms. Achtypi S., Ms. Kaplanidi H., Mr. Papaelias S., Mr. Mavroulis S., Dr. Michelioudakis D. and Ms. Drosopoulou E. for their valuable contribution to the field measurements.

Funding The fieldwork was supported by the Special Account for Research Grants of the UoA (Contract No. 70/4/9254).

Data availability Data will be made available on request.

\section{Compliance with ethical standards}

Conflict of interest The authors declare that they have no conflict of interest.

\section{References}

1. Ammirati JB, Venerdini A, Alcacer JM, Alvarado P, Miranda S, Gilbert $\mathrm{H}$ (2018) New insights on regional tectonics and basement composition beneath the eastern Sierras Pampeanas (Argentine back-arc region) from seismological and gravity data. Tectonophysics 740:42-52. https://doi.org/10.1016/j.tecto.2018.05.015

2. An Z, Di Q (2016) Investigation of geological structures with a view to HLRW disposal, as revealed through 3D inversion of aeromagnetic and gravity data and the results of CSAMT exploration. J Appl Geophys 135:204-211. https://doi.org/10.1016/j. jappgeo.2016.10.013

3. Andersson M, Malehmir A (2018) Internal architecture of the Alnö alkaline and carbonatite complex (central Sweden) revealed using 3D models of gravity and magnetic data. Tectonophysics 740-741:53-71. https://doi.org/10.1016/j.tecto .2018.05.008

4. Anudu GK, Stephenson RA, Macdonald DI, Oakey GN (2016) Geological features of the northeastern Canadian Arctic margin revealed from analysis of potential field data. Tectonophysics 691:48-64. https://doi.org/10.1016/j.tecto.2016.03.025

5. Avigad D, Ziv A, Garfunkel Z (2001) Ductile and brittle shortening, extension-parallel folds and maintenance of crustal thickness in the central Aegean (Cyclades, Greece). Tectonics 20(2):277-287. https://doi.org/10.1029/2000TC001190
6. Azab AA, El-Khadragy AA (2013) 2.5-D Gravity/magnetic model studies in Sahl El Qaa Area, Southwestern Sinai, Egypt. Pure Appl Geophys 170(12):2207-2229. https://doi.org/10.1007/s0002 4-013-0650-5

7. Azizi M, Saibi $H$ (2015) Integrating gravity data with remotely sensed data for structural investigation of the Aynak-Logar Valley, eastern Afghanistan, and the surrounding area. IEEE J Select Top Appl Earth Observ Remote Sens 8(2):816-824. https://doi. org/10.1109/JSTARS.2014.2347375

8. Berg JW, Thiruvathukal JV (1965) Gravity base station network, Oregon. J Geophys Res 70(14):3325-3330. https://doi. org/10.1029/JZ070i014p03325

9. Bersi M, Saibi H, Chabou MC (2016) Aerogravity and remote sensing observations of an iron deposit in Gara Djebilet, southwestern Algeria. J Afr Earth Sc 116:134-150. https://doi. org/10.1016/j.jafrearsci.2016.01.004

10. Blaikie TN, Ailleres L, Betts PG, Cas RAF (2014) Interpreting subsurface volcanic structures using geologically constrained 3-D gravity inversions: examples of maar-diatremes, Newer Volcanics Province, southeastern Australia. J Geophys Res Solid Earth 119(4):3857-3878. https://doi.org/10.1002/2013JB010751

11. Blecha V, Štemprok M, Fischer T (2009) Geological interpretation of gravity profiles through the Karlovy Vary granite massif (Czech Republic). Stud Geophys Geod 53(3):295-314. https:// doi.org/10.1007/s11200-009-0019-5

12. Boszczuk P, Cheng LZ, Hammouche H, Roy P, Lacroix S, Cheilletz A (2011) A 3D gravity data interpretation of the Matagami mining camp, Abitibi Subprovince, Superior Province, Québec, Canada: Application to VMS deposit exploration. J Appl Geophys 75(1):77-86. https://doi.org/10.1016/j.jappgeo.2011.06.031

13. Casten U, Snopek K (2006) Gravity modelling of the Hellenic subduction zone - A regional study. Tectonophysics 417(3-4):183200. https://doi.org/10.1016/j.tecto.2005.11.002

14. Choi S, Götze HJ, Meyer U, DESIRE Group (2011) 3-D density modelling of underground structures and spatial distribution of salt diapirism in the Dead Sea Basin. Geophys J Int 184(3):11311146. https://doi.org/10.1111/j.1365-246X.2011.04939.x

15. Coleman M, Soukis K, Schnider D, Grasemann B, Lozios S (2018) The northwest termination of the West Cy-cladic Detachment System in Central Attica. In: EGU General Assembly Conference Abstracts, vol 20, pp 5172.

16. Commer M (2011) Three-dimensional gravity modelling and focusing inversion using rectangular meshes. Geophys Prospect 59(5):966-979. https://doi.org/10.1111/j.1365-2478.2011.00969 .$x$

17. Csapó G, Völgyesi L (2002) Hungary's new gravity base network (MGH-2000) and it's connection to the European unified gravity net. In: József Á, Klaus-Peter S (eds) Vistas for Geodesy in the New Millennium. Springer, Berlin, pp 72-77

18. Curto JB, Vidotti RM, Blakely RJ, Fuck RA (2015) Crustal framework of the northwest Paraná Basin, Brazil: Insights from joint modeling of magnetic and gravity data. Tectonophysics 655:5872. https://doi.org/10.1016/j.tecto.2015.05.011

19. Damaceno JG, de Castro DL, Valcácio SN, Souza ZS (2017) Magnetic and gravity modeling of a Paleogene diabase plug in Northeast Brazil. J Appl Geophys 136:219-230. https://doi. org/10.1016/j.jappgeo.2016.11.006

20. de Castro DL, Fuck RA, Phillips JD, Vidotti RM, Bezerra FH, Dantas EL (2014) Crustal structure beneath the Paleozoic Parnaíba Basin revealed by airborne gravity and magnetic data, Brazil. Tectonophysics 614:128-145. https://doi.org/10.1016/j.tecto .2013.12.009

21. Dilalos S. (2018) Application of geophysical technique to the investigation of tectonic structures in urban and suburban environments. A case study in Athens basin. Ph.D. Thesis National and Kapodistrian University of Athens. 
22. Dilalos S, Alexopoulos JD (2017) Indications of correlation between gravity measurements and isoseismal maps. A case study of Athens basin (Greece). J Appl Geophys 140:62-74. https ://doi.org/10.1016/j.jappgeo.2017.03.012

23. Dilalos S, Alexopoulos JD (2019) Urban Gravity Measurements for the Subsurface Investigation of Athens Basin (Greece). Bull Geol Soc Greece Spec Publ 7:211-212

24. Dilalos S., Alexopoulos J.D. (2019b) Quantitative subsurface information of Athens basin (Greece) derived from urban gravity measurements. In: Near Surface Geoscience 2019-1st Conference on Geophysics for infrastructure planning monitoring and BIM:We_INFRA_P23. https://doi.org/10.3997/2214-4609.20190 2560

25. Dilalos S, Alexopoulos JD, Lozios S (2019) New insights on Athens basin (Greece) subsurface geological and tectonic structure, derived from urban gravity measurements. J Appl Geophys 167:73-105. https://doi.org/10.1016/j.jappgeo.2019.04.024

26. Dilalos S., Alexopoulos J.D., Lozios S. (2019b) The contribution of urban gravity survey to the subsurface geological structure of the Athens basin (Greece). In: Near Surface Geoscience 201925th European meeting of environmental and engineering geophysics:We_25_P17.https://doi.org/10.3997/2214-4609.20190 2472

27. Dilalos S, Alexopoulos JD, Tsatsaris A (2018) Calculation of Building Correction for urban gravity surveys. A case study of Athens metropolis (Greece). Journal of Applied Geophysics 159:540552. https://doi.org/10.1016/j.jappgeo.2018.09.036

28. European Environment Agency (2012) CORINE Land Cover Project

29. Farhi W, Boudella A, Saibi H, Bounif MOA (2016) Integration of magnetic, gravity, and well data in imaging subsurface geology in the Ksar Hirane region (Laghouat, Algeria). J Afr Earth Sc 124:63-74. https://doi.org/10.1016/j.jafrearsci.2016.09.013

30. Fernandez-Cordoba J, Zamora-Camacho A, Espindola JM (2017) Gravity Survey at the Ceboruco Volcano Area (Nayarit, Mexico): A 3-D Model of the Subsurface Structure. Pure Appl Geophys 174(10):3905-3918. https://doi.org/10.1007/s00024-017-1600-4

31. FitzGerald D, Reid A, McInerney P (2004) New discrimination techniques for Euler deconvolution. Comput Geosci 30(5):461469. https://doi.org/10.1016/j.cageo.2004.03.006

32. Freyberg BV (1951) Das Neogen-Gebiet nordwestlich Athen. Annales Géologiques des Pays Helléniques 3:65-86 (in German)

33. Grasemann B, Schneider D, Stöckli D, Iglseder C (2012) Miocene bivergent crustal extension: evidence from the western Cyclades (Greece). Lithosphere 4(1):23-39. https://doi. org/10.1130/L164.1

34. Hipkin RG, Lagios E, Lyness D, Jones $P$ (1988) Reference gravity stations on the IGSN71 standard in Britain and Greece. Geophys J Int 92(1):143-148. https://doi.org/10.1111/j.1365-246X.1988. tb01128.x

35. Hosseini AA, Doulati AF, Tabatabaie SH, Hezarkhani A (2013) Edge detection in gravity field of the Gheshm sedimentary basin. Int J Min Geo Eng 47(1):41-50. https://doi.org/10.22059/ IJMGE.2013.50089

36. Iglseder C, Grasemann B, Rice AHN, Petrakakis K, Schneider DA (2011) Miocene south directed low-angle normal fault evolution on Kea Island (West Cycladic Detachment System, Greece). Tectonics 30(4):1-31. https://doi.org/10.1029/2010TC002802

37. Katsikatsos G. (1977) La structure tectonique d'Attique et de lîle d'Eubée. In: Proceedings of the 6th colloquium of the geology of the Aegean Region, vol 1, pp 211-228, IGME publications (in French).

38. Katsikatsos G., Migiros G., Triantaphyllis M., Mettos A. (1986) Geological structure of internal Hellenides (E. Thessaly-SW Macedonia-Euboea-Attica-Northern Cyclades islands and Lesvos).
Geological and Geophysical Research Special Issue, pp 191-212. IGME publications, New York

39. Keating PB (1998) Weighted Euler deconvolution of gravity data. Geophysics 63(5):1595-1603. https://doi.org/10.1190/1.14444 56

40. Khalil MA, Santos FM, Farzamian M (2014) 3D gravity inversion and Euler deconvolution to delineate the hydro-tectonic regime in El-Arish area, northern Sinai Peninsula. J Appl Geophys 103:104-113. https://doi.org/10.1016/j.jappgeo.2014.01.012

41. Khamies AA, El-Tarras MM (2010) Surface and subsurface structures of Kalabsha area, southern Egypt, from remote sensing, aeromagnetic and gravity data. Egypt J Remote Sens Space Sci 13(1):43-52. https://doi.org/10.1016/j.ejrs.2010.07.006

42. Kim YM, Lee SM, Okino K (2009) Comparison of gravity anomaly between mature and immature intra-oceanic subduction zones in the western Pacific. Tectonophysics 474(3-4):657-673. https ://doi.org/10.1016/j.tecto.2009.05.004

43. Koumetio F, Njomo D, Tabod CT, Noutchogwe TC, ManguelleDicoum E (2012) Structural interpretation of gravity anomalies from the Kribi-Edea zone, South Cameroon: a case study. J Geophys Eng 9(6):664. https://doi.org/10.1088/1742-2132/9/6/664

44. Krohe A, Mposkos E, Diamantopoulos A, Kaouras G (2010) Formation of basins and mountain ranges in Attica (Greece): the role of Miocene to Recent low-angle normal detachment faults. Earth Sci Rev 98(1-2):81-104. https://doi.org/10.1016/j.earsc irev.2009.10.005

45. Krynski J, Olszak T, Barlik M, Dykowski P (2013) New gravity control in Poland-needs, the concept and the design. Geodesy Cartogr 62(1):3-21. https://doi.org/10.2478/geocart-2013-0001

46. Lagios E (1985) A gravity network in central Greece for secular gravity studies. Pure Appl Geophys 123(1):81-90. https://doi. org/10.1007/BF00877050

47. Le Pourhiet L, Huet B, May DA, Labrousse L, Jolivet L (2012) Kinematic interpretation of the 3D shapes of metamorphic core complexes. Geochem Geophys Geosyst 13(9):Q09002. https:// doi.org/10.1029/2012GC004271

48. Leader LD, Rawling TJ, Wilson CJL (2006) Structural transect and forward modelling of geophysical data across the St Arnaud Group, Victoria. Austr J Earth Sci 53(5):863-873. https://doi. org/10.1080/08120090600827504

49. Lekkas S, Lozios S (2000) Tectonic structure of Mt. Hymittos Annales Géologiques des Pays Helléniques 38:47-62

50. Lekkas S, Skourtsos E, Soukis K, Kranis H, Lozios S, Alexopoulos A, Koutsovitis P. (2011) Late Miocene detachment faulting and crustal extension in SE Attica (Greece). Geophysical Research Abstracts 13: EGU2011-13016.

51. Lepsius R. (1893) Geologie von Attika. Ein Beitrag zur Lehre von Metamorphismus der Gesteine, Berlin Zeitschr. f. prakt. Geol. 4:196S. (in German).

52. Levy F, Jaupart C (2011) Folding in regions of extension. Geophys J Int 185(3):1120-1134. https://doi.org/10.1111/j.1365246X.2011.05013.X

53. Lozios $S$ (1993) Tectonic analysis of the metamorphic formations of NE Attica. PhD Thesis, National and Kapodistrian University of Athens (in Greek) https://hdl.handle.net/10442/hedi/2925

54. Makris J, Papoulia J, Yegorova T (2013) A 3-D density model of Greece constrained by gravity and seismic data. Geophys J Int 194(1):1-17. https://doi.org/10.1093/gji/ggt059

55. Marinos G, Katsikatsos G, Georgiadou-Dikeoulia E, Mirkou E (1971) The Athens' schist formation I. Stratigraphy and structure. Annales Géologiques des Pays Helléniques 23:183-212 (in Greek)

56. Marinos G, Katsikatsos G, Mirkou E (1974) The Athens' schist formation II. Stratigraphy and Structure. Annales Géologiques des Pays Helléniques 25:439-444 (in Greek) 
57. Mariolakos I, Fountoulis I, Mariolakos D, Andreadakis E, Georgakopoulos A (2000) Geodynamic phenomena observed during the Athens earthquake (Ms=5.9) 7-9-1999. Annales Géologiques des Pays Helléniques 38:175-186

58. Martinez C, Li Y, Krahenbuhl R, Braga MA (2013) 3D inversion of airborne gravity gradiometry data in mineral exploration: a case study in the Quadrilátero Ferrífero Brazil. Geophysics 78(1):B1B11. https://doi.org/10.1190/geo2012-0106.1

59. Martins-Ferreira MAC, Campos JEG, Von Huelsen MG, Neri BL (2018) Paleorift structure constrained by gravity and stratigraphic data: the Statherian Araí rift case. Tectonophysics 738739:64-82. https://doi.org/10.1016/j.tecto.2018.05.014

60. Miller CA, Williams-Jones G, Fournier D, Witter J (2017) 3D gravity inversion and thermodynamic modelling reveal properties of shallow silicic magma reservoir beneath Laguna del Maule, Chile. Earth Planet Sci Lett 459:14-27. https://doi.org/10.1016/j. epsl.2016.11.007

61. Morelli C, Gantar C, Honkasalon T, McConnel K, Tanner JG, Szabo B, Uotila U, Whalen CT (1974) The International Standardization Net 1971 (IGSN71). In: IUGG-IAG Publication Special 4. International Union of Geodesy and Geophysics.

62. Naouali BS, Inoubli MH, Amiri A, Chaqui A, Hamdi I (2011) Subsurface geology of the Ariana region (Diapir Zone, northern Tunisia) by means of gravity analysis. Geophys Prospect 59(6):983-997. https://doi.org/10.1111/j.1365-2478.2011.01004 .$x$

63. Nasr IH, Amiri A, Inoubli MH, Salem AB, Chaqui A, Tlig S (2011) Structural setting of northern Tunisia insights from gravity data analysis Jendouba case study. Pure Appl Geophys 168(10):18351849. https://doi.org/10.1007/s00024-010-0189-7

64. Niedermayer J (1971) Die geologische Karte von Athen 1:10.000. Bull Geol Soc Greece 8(2):117-134 (in German)

65. Papadopoulos TD, Goulty N, Voulgaris NS, Alexopoulos JD, Fountoulis I, Kambouris P, Karastathis V, Peirce C, Chailas S, Kassaras J, Pirli M (2007) Tectonic structure of Central-Western Attica (Greece) based on geophysical investigations-preliminary results. Bull Geol Soc Greece 40(3):1207-1218

66. Papanikolaou D (1986) Geology of Greece. Heptalofos, Athens (in Greek)

67. Papanikolaou D, Lozios S, Sideris C, Kranis H, Danamos $G$, Soukis K, Skourtsos E, Bassi E, Marinos P, Tsiampaos G, Boukovalas G, Sabatakakis N, Antoniou A, Provia K (2002) Geological-Geotechnical study of Athens basin. OASP Applied Research Program, Athens (in Greek)

68. Papanikolaou DI, Lozios SG, Soukis K, Skourtsos E (2004) The geological structure of the allochthonous 'Athens Schists'. Bull Geol Soc Greece 36(4):1550-1559 (in Greek)

69. Park CH, Kim JW, Isezaki N, Roman DR, von Frese RR (2006) Crustal analysis of the Ulleung Basin in the East Sea (Japan Sea) from enhanced gravity mapping. Mar Geophys Res 27(4):253-266. https://doi.org/10.1007/s11001-006-9006-1

70. Prutkin I, Vajda P, Tenzer R, Bielik M (2011) 3D inversion of gravity data by separation of sources and the method of local corrections: Kolarovo gravity high case study. J Appl Geophys 75(3):472-478. https://doi.org/10.1016/j.jappgeo.2011.08.012

71. Reid A.B., Ebbing J., Webb S.J. (2012) Comment on 'A crustal thickness map of Africa derived from a global gravity field model using Euler deconvolution'by Getachew E. Tedla, M. van der Meijde, AA Nyblade and FD van der Meer. Geophys J Int 189(3):1217-1222. https://doi.org/10.1111/j.1365246X.2012.05353.x
72. Reid AB, Ebbing J, Webb SJ (2014) Avoidable Euler errorsthe use and abuse of Euler deconvolution applied to potential fields. Geophys Prospect 62(5):1162-1168. https://doi. org/10.1111/1365-2478.12119

73. Reid AB, Thurston JB (2014) The structural index in gravity and magnetic interpretation: Errors, uses, and abuses. Geophysics 79(4):J61-J66. https://doi.org/10.1190/geo2013-0235.1

74. Robertson El (1965) Gravity base stations in the south-west Pacific Ocean. NZ J Geol Geophys 8(3):424-439. https://doi. org/10.1080/00288306.1965.10426414

75. Sabatakakis N (1991) Engineering geological setting of Athens basin. Ph.D. Thesis University of Patras (in Greek) https://hdl. handle.net/10442/hedi/1734

76. Seman S, Soukis K, Stockli DF, Skourtsos E, Kranis H, Lozios S (2012) Novel Thermochrono-metric Techniques Applied to the Lavrion Detachment, Lavrion Peninsula, Attica, Greece. Miner Mag Abstracts 76:2352

77. Seman S, Soukis K, Stockli DF, Skourtsos E, Kranis H, Lozios S (2013) Provenance of metasediments and Miocene exhumation history of the Lavrion Peninsula, South Attica, Greece: a combined structural, (U-Th)/He, and detrital zircon U-Pb study. Geophys Res Abstracts 15:EGU2013-12605.

78. Slack HA, Lynch VM, Langan L (1967) The geomagnetic gradiometer. Geophysics 32(5):877-892. https://doi.org/10.1190/1.14398 97

79. Smith N, Cassidy J, Locke CA, Mauk JL, Christie AB (2006) The role of regional-scale faults in controlling a trapdoor caldera, Coromandel Peninsula, New Zealand. J Volcanol Geoth Res 149(34):312-328. https://doi.org/10.1016/j.jvolgeores.2005.09.005

80. Srivastava RP, Vedanti N, Dimri VP (2015) New gravity bases in Jabera-Damoh Vindhyan basin, central India. J Geol Soc India 85(3):359-366. https://doi.org/10.1007/s12594-015-0225-4

81. Tedla GE, Van Der Meijde M, Nyblade AA, Van der Meer FD (2011) A crustal thickness map of Africa derived from a global gravity field model using Euler deconvolution. Geophys J Int 187(1):1-9. https://doi.org/10.1111/j.1365-246X.2011.05140.x

82. Wang G, Zhang S, Yan C, Song Y, Sun Y, Li D, Xu F (2011) Mineral potential targeting and resource assessment based on 3D geological modeling in Luanchuan region China. Comput Geosci 37(12):1976-1988. https://doi.org/10.1016/j.cageo.2011.05.007

83. Warsi WE (1989) Gravity bases in the State of Kuwait. J Univ Kuwait-Sci 16(2):433-447

84. Wehr H, Chevrot S, Courrioux G, Guillen A (2018) A three-dimensional model of the Pyrenees and their foreland basins from geological and gravimetric data. Tectonophysics 734:16-32. https://doi.org/10.1016/j.tecto.2018.03.017

85. Weidmann C, Gimenez M, Klinger FL, Alvarez O (2016) Anomalous values of gravity and magnetism in the western margin of Gondwana. Tectonophysics 667:1-15. https://doi.org/10.1016/j. tecto.2015.11.017

86. Xypolias P, Kokkalas S, Skourlis K (2003) Upward extrusion and subsequent transpression as a possible mechanism for the exhumation of HP/LT rocks in Evia Island (Aegean Sea, Greece). J Geodyn 35(3):303-332. https://doi.org/10.1016/S0264 $-3707(02) 00131-X$

Publisher's Note Springer Nature remains neutral with regard to jurisdictional claims in published maps and institutional affiliations. 